JURNALYOGA DAN KESEHATAN

JURUSAN YOGA KESEHATAN

FAKULTAS BRAHMA WIDYA

IHDN DENPASAR
Vol. 3 No. 1 Maret 2020

ISSN : 2621-0185 (Cetak)

http://ejournal.ihdn.ac.id/index.php/jyk

\title{
Tatěngĕr : Diagnosa dalam Usadha Bali
}

\section{Putu Suweka Oka Sugiharta}

Instansi Pelaksana Program Keluarga Harapan (PPKH) Kabupaten Karangasem

email :suwekaoka@gmail.com

Diterima tanggal 7 November 2019, diseleksi tanggal 7 Desember 2019, dan disetujui tanggal 26 Desember 2019

\section{ABSTRACT}

Tatěngĕr occupies a very important role in Balinese usadha. Although not exactly the same, Tatĕngĕr has similarities with diagnosis in medical treatment. In Bali there are various ways to diagnose both those that originate from oral tradition and text tradition. Sometimes between one healer and another healer has a different way to detect the patient's disease. A healer learns the diagnosis from reading traditional medical books (lontar usadha), learning from a teacher, or discovering it based on his experience.Sometimes a balian is able to detect disease through ways that are not understood by general logic, even his own reason. This phenomenon is known in Bali as a horn. Of course, how to detect this kind of disease is very difficult to teach others. Given the variety of ways of diagnosing diseases in the Balinese usadha, studies in this field can be done to the widest possible range of perspectives.

\section{Keywords: Tatěngĕr, Diagnosis, Usadha Bali}

\section{ABSTRAK}

Tatěngěr menduduki peran yang sangat penting dalam usadha Bali. Meskipun tidak sama persis,Tatěngěr memiliki kemiripan dengan diagnose dalam pengobatan medis. Di Bali terdapat berbagai cara untuk melakukan diagnose baik yang bersumber dari tradisi lisan maupun tradisi teks. Terkadang antara satu penyembuh dengan penyembuh lain memiliki cara yang berbeda untuk mendeteksi penyakit pasien. Seorang penyembuh mempelajari diagnosa dari membaca kitab pengobatan tradisional (lontar usadha), belajar dari seorang guru, maupun menemukan sendiri berdasarkan pengalamannya. Terkadang seorang balian mampu melakukan deteksi penyakit melalui cara-cara yang tidak dipahami oleh logika umum, bahkan nalarnya sendiri. Fenomena semacam ini di Bali dikenal dengan katakson. Tentu saja cara mendeteksi penyakit semacam ini sangat sulit diajarkan kepada orang lain. Mengingat beragamnya cara diagnosa penyakit dalam usadha Bali, kajian dalam bidang ini bisa dilakukan seluas-luasnya dari beragam perspektif.

\section{Kata Kunci :Tatěngĕr, Diagnosa, Usadha Bali}

\section{Pendahuluan}

Pengobatan tradisional tetap memiliki pendukung di tengah meluasnya paham bio medisin barat yang berkembang demikian pesat. Kendatipun terkadang pengobatan tradisional dihinggapi oleh citra-citra negatif seperti kurangnya kehigienisan, cenderung membawa pasien 
ke dunia irasional, serta standarisasi, kontrol, hingga sertifikasi yang masih sulit dilakukan. Kenyataannya jenis pengobatan ini tidak segera ditinggalkan. Penyebabnya bukan semata alasan ekonomi seperti biaya berobat yang lebih terjangkau dari pengobatan medis. Primasari (2016:127) menyebut pengobatan tradisional sebagai salah satu upaya pengobatan atau perawatan dengan cara lain di luar ilmu kedokteran atau ilmu keperawatan yang banyak dimanfaatkan oleh masyarakat dalam mengatasi masalah-masalah kesehatan, pencegahan penyakit, penyembuhan penyakit, dan pemulihan kesehatan. Titik berat pendapat Primasari terletak pada ketegasan penyebutan pengobatan tradisional berada di luar ilmu kedokteran atau keperawatan (modern). Kendatipun sempat ada wacana Gubernur Koster untuk menyertakan pengobat tradisional pada pusat-pusat kesehatan modern, antara keduanya tetap terlihat berbeda. Bahkan ada kesan jika penghadiran pengobatan tradisional di pusat-pusat kesehatan modern sebagai penambal kelemahan-kelemahan yang tidak bisa diatasi oleh pengobatan medis.

Pengobatan tradisional terutama sekali lekat dengan jenis penyakit nonmedis yang tidak mampu didiagnosa dengan cara-cara medis. Hakim (2010:156) menyatakan sepintas antara penyakit medis dan non medis sulit dibedakan karena penderita merasakan sakit yang hampir sama. Lebih lanjut Hakim menekankan jika gangguan utama penyakit nonmedis adalah pada jiwa manusia, bukan pada fisik/ jasadnya. Terdapat dua sikap orang sakit beserta keluarganya atas keberadaan menyakit non medis. Berdasarkan cara penyikapan tersebut akan diketahui pula sistem keyakinan dominan si sakit/ keluarganya. Orang-orang yang berpikiran orthodox/ tradisional umumnya akan menghubungkan penyakit apapun dengan hal-hal nonmedis, oleh karenanya upaya pengobatanpun akan dimulai dari cara-cara tradisional. Setelah cara tradisional ditempuh dan tampak tidak ada tanda kesembuhan pada si sakit barulah akan dilanjutkan ke pengobatan medis. Bahkan ada kelompok yang fanatik pada cara-cara nonmedis dan tetap melanjutkan upaya-upaya tradisional kendatipun tidak menemukan titik terang. Sebaliknya orang-orang yang berpikiran modern akan memulai upaya pengobatan medis. Setelahnya bila tidak ada perkembangan barulah dipertimbangkan menempuh pengobatan nonmedis.

Selain aspek nonmedis, dalam pengobatan tradisional terkandung pula unsur-unsur fisikal yang dapat dibuktikan dengan cara-cara ilmiah. Secara farmakologis pengobatan tradisional dinilai mampu meminimalisir dampak-dampak negatif bahan kimia obat dengan penggunaan bahan-bahan herbal meskipun tetap memperhatikan dosis pemakaian. Sebagaimana diungkapkanPermadi (2006:8) walaupun terdapat kesamaan antara obat kimia dengan tanaman obat diuretic dalam hal fungsinya, namun keduanya memiliki perbedaan. Tanaman obat diuretik selain memiliki efek diuretik juga memiliki efek lain seperti memperbaiki organ dan system yang rusak, disamping diperoleh pula efek tambahan misalnya antiradang, analgesik, 
melancarkan peredaran darah, antitoksik, serta yang lainnya. Walaupun pengobatan herbal juga punya kelemahan. Satu hal yang harus dipahami adalah obat herbal bekerjanya (hasilnya) tidak cepat (Suparti, 2017:208)

\section{PEMBAHASAN}

\subsection{Pengertian Tatěngĕr}

Kata tatĕngĕr berasal dari kata dasar těngĕr yang berarti berciri, kedengaran, atau mengandung unsur yang khas. Misalnya ada kalimat kulkul banjarè nganti dini matěngĕran (kentongan milik banjar sampai disini kedengaran). Berarti si pendengar dapat memastikan jika suara yang didengarnya berasal dari kentongan banjar, bukan dari kentongan lain atau benda bersuara lainnya. Kemampuan untuk memberikan kesimpulan tersebut pastilah didasarkan pada pengalaman mendengarkan yang dilakukan secara berulang-ulang. Atau bandingkan dengan kalimat berikutnya Tĕngĕran munyinè I Dugdug uli joh suba maciri (gema suaranya I Dugdug dari jauh sudah ketara). Si pendengar dengan cepat bisa mengenali I Dugdug dari ciri suaranya meskipun tidak melihat wajahnya secara langsung. Kata tĕngĕr dalam Bahasa Bali merupakan serapan dari bahasa Jawa Kuna tĕyĕr. Terkait dengan Usada Bali istilah tatěngĕr diartikan sebagai upaya yang dilakukan Balian untuk mengenali penyakit yang diderita pasien berdasarkan ciri atau tandanya yang khas. Kemampuan yang dimiliki Balian dapat berasal dari pengalaman, proses belajar, maupun bakat yang diperoleh dari kelahirannya.

Sugiharta (2018:188) menyatakan jika istilah Balian salah satunya diduga berasal dari kata maliin yang berarti kemampuan untuk mengecek atau mendiagnosa kondisi pasiennya. Padanan kata yang mendekati makna tatěngěr dalam ilmu kedokteran modern adalah diagnosis. Clyne (dalam Balint dan Norell, ed, 1973:58) menyatakan diagnosis berasal dari bahasa Yunani yakni dari kata kerja diagignoskein yang berarti membedakan (to distinguish, discern).Selanjunya Clyne mengutip The Shorter Oxford English Dictionary (1968) bahwaketika digunakan dalam konteks penyimpulan suatu penyakit dapat berarti ketetapan hati/ keyakinan atas sifat alamiah dari suatu kondisi sakit: identifikasi atas penyakit (determination of the nature of a diseased condition: identification of a disease).Disamping itu Clyne juga menjelaskan jika pada mulanya para penyembuh tidak merasa perlu untuk mengidentifikasi penyakit dengan mendetail, sebagai contoh literatur-literatur Hipokrates menyimpulkan penyakit hanya secara umum dan tersamar/ambigu. Misalnya jenis penyakit yang paling sering digambarkan terbatas pada krisis (crisis), demam (fever), dan sawan/ ayan (apoplexy). Pengetahuan yang mapan tentang diagnosis dipandang lahir bersamaan dengan diperhitungkannya aspek psikologi dan proses patologis sebagai kajian ilmu alam. 
Berbeda dengan pandangan Clyne yang mengacu pada perkembangan ilmu diagnosis di barat, dalam Usadha Bali keberadaan diagnosis menjadi perhatian utama para penyembuh. Gejala-gejala penyakit tidak digeneralisir sehingga menimbulkan kesan tersamar/ ambigu, sebaliknya beberapa lontar malah mendeskripsikan suatu jenis penyakit dengan sangat spesifik beserta variasi-variasinya. Diagnosis memegang peranan penting dalam proses pengobatan baik yang bersifat modern maupun tradisional. Hardjodisastro, (2006:49) menyatakan diagnosis sebenarnya sangat rumit (ruwet) sekaligus merupakan seni karena menentukan sesuatu dengan bahan yang sangat tidak menentu (to make a decision with the uncertain data), sedangkan keputusan tersebut tidak boleh salah. Dengan demikian sangatlah mustahil seorang penyembuh dapat mencapai keprofesionalannya tanpa kemampuan diagnosis yang mumpuni kecuali terjadi secara kebetulan dan tentu kebetulan yang menguntungkan sangat jarang terulang.Diagnosis serupa dengan memperkirakan bagian yang lowong pada bagian puzzle untuk dilengkapi dengan potongan yang pas. Kesalahan mendiagnosa selain menimbulkan kesia-siaan pengobatan atau terhambatnya proses penyembuhan juga membahayakan jiwa pasien akibat penanganan yang keliru.Secara tradisional menurut Delf dan Manning (1996:3) diagnosis dilakukan melalui empat cara yakni melihat (inspeksi), meraba (palpasi), mengetuk (perkusi), dan mendengar (auskultasi).

\subsection{Diagnosa dalam Pengobatan Tradisional: Sebuah Perbandingan}

Sistem pengobatan tradisional yang terintegrasi dalam beraneka rupa kebudayaan di berbagai belahan dunia sesungguhnya telah mencitrakan teknik-teknik diagnosis baik yang terlihat memiliki kemiripan satu dengan yang lainnya maupun berbeda samasekali. Tentu usadha Bali tidak bisa dilihat sebagai system pengobatan yang mandiri seutuhnya tanpa pengaruh luar sebab pulau Bali semenjak lampau tidaklah terisolir dari dunia luar. Kontak dengan orang-orang dari seberang lautan menyebabkan munculnya pengayaan-pengayaan dalam pengobatan tradisonal Bali tetapi unsur asli Usadha Bali masih tetap terpelihara. Terbukti sangat banyak peneliti dari luar yang ingin mengetahui lebih jauh tentang pengobatan tradisional Bali, tentu ini karena sifat khasnya yang tidak dapat ditemui di belahan bumi manapun. Walaupun begitu untuk memperluas pemahaman, keberadaan diagnosis tradisional di luar Bali perlu juga diketahui sehingga ke depan dari kemiripan maupun perbedaannya diharapkan dapat terlacak. Kemiripan dan perbedaan kemudian menuntun kepada hubungan pengaruh mempengaruhi, siapa yang memberikan pengaruh dan siapa saja yang dipengaruhi, serta unsur mana saja yang belum tersentuh oleh pengaruh. Pengkajian-pengkajian semacam ini menjadi sangat krusial untuk selain untuk mengetahui hubungan baik yang telah terpelihara sejak lama juga menggambarkan terjadinya penyempurnaan tiada henti. Suatu teknik yang dianggap terlalu lemah diperlengkapi 
dengan teknik penyempurna yang berasal dari luar demikian juga teknik yang mapan tidak akan geming mesti tawaran-tawaran dari luar membanjir.

Dalam sebagian besar kebudayaan pada tahap mistis penyakit dominan dianggap berasal bersifat nonfisik. Delf dan Manning (1996:3-4) menyatakan diagnosis fisik belum disadari artinya sampai permulaan abad XIX. Sebabhampir selama setengah bagian dari masa sejarah yang tertulis penyakit cenderung dipandang berasal dari sumber gaib. Penyakit-penyakit yang menjangkiti manusia diyakini berasal dari para dewa atau melalui perantaraan seorang cenayang sebagai bentuk hukuman atas dosa yang diperbuat si sakit karena melanggar aturan yang berlaku pada sukunya. Manakala penyakit dilihat dalam kerangka kegaiban artinya pengetahuan mengenai anatomi maupun psikologi tidak berarti samasekali. Delf dan Manning lebih jauh mencontohkan dengan mengutip tulisan karya seorang penulis Yunani yang dibuat sekira 400 tahun sebelum Masehi. Dalam tulisan tersebut digambarkan seorang kepala suku berbadan kekar tengah duduk di dekat api unggun dengan perasaan kagum dan bangga atas kemenangan perang yang baru saja diperolehnya. Tetiba orang besar ini mengeluarkan teriakan menakutkan kemudian jatuh tersungkur, tubuhnya meliuk-liuk memperlihatkan terjadinya serangan kejang di sekujur tubuhnya, mulunya mengeluarkan busa berbuih, air kencing beserta kotorannya berserakan tanpa kendali, serta lidahnya terluka akibat gigitan yang terlalu kuat. Sekira 10 menit selepas munculnya gejala pertama si kepala suku tertidur sangat nyenyak dan baru terbangun satu jam kemudian. Anehnya ketika terbangun dari kenyamanan tidurnya ia seakan linglung, tidak mampu mengingat kejadian yang baru saja dialaminya bahkan sisa-sisa dari penderitaan sebelumnya juga tidak tampak. Semua berjalan normal seakan tidak pernah terjadi suatu kejadian yang menegangan. Kelompok suku yang masih berkeyakinan penuh jika penyakit berasal dari kekuatan gaib tentu sangat yakin bila penderitaan aneh yang menimpa sang kepala suku tiada lain dari pewujudan kuasa dewa-dewa. Seandainyapun kejadian semacam itu terjadi pasca perkembangan pesat ilmu kedoteran pada suku-suku yang masih tertinggal atau masyarakat yang telah maju namun tanpa ada anggotanya mempelajari ilmu kedokteran secara khusus maka tudingan atas campur tangan kuasa gaib tidak dapat dihindari. Hanya orang-orang yang mempelajari ilmu kedokteran secara mendalamlah yang mampu mengidentifikasi dengan penuh keyakinan bahwa gejala serupa itu sebagai epilepsi.

Teknik diagnosis tradisional masih membayangi ilmu kedokteran era Abad Pertengahan hingga Zaman Renaissance. Setidaknya diagnosis memanfaatkan tiga cara seperti astrologi, penghitungan denyut nadi yang penuh khayalan, serta uroskopi (pengamatan air kemih). Kini ketika ilmu kedokteran tampaknya dominan mengandalkan diagnosis fisik, cara-cara tradisional yang seringkali dijadikan bahan olok-olok ditelaah kembali ketika diagnosis fisik mengalami 
kebuntuan. Terbukti banyak dokter yang dijejali teori-teori kedokteran barat berbalik tertarik dengan konsep energy, cakra, astrologi, aura, dan semacamnya.

\subsubsection{Cina}

Diagnosis sangat mendukung kemajuan yang dicapai pengobatan Cina yang diperkirakan telah berembrio sekitar 5000 tahun lampau. Sedangkan menurut Basya (2015:356) Shi Nang (2698-2738 sebelum masehi) telah mengenal gejala-gejala sakit asma yang diobati dengan bagian pohon Avendra.Para tabib mulanya hanya berpraktek di lingkungan istana untuk mengobati Kisar beserta kerabat kerajaan. Tabib-tabib istana memulai kepiawaiannya dengan kecermatan diagnosa, dimana kemampuan ini tidak didapatkan begitu saja. Ketika kaisar menunjukkan gejala penyakit tertentu maka para tabib akan mencermati gejala penyakitnya dengan hati-hati. Setelahnya dikumpulkanlah rakyat yang menunjukkan gejala penyakit serupa untuk diobati secara spekulatif. Cara atau bahan obat yang terbukti membawa kesembuhan paling cepat akan diaplikasikan untuk menangani kaisar. Diagnosa dalam pengobatan Cina tidak hanya wajib dilakukan pada pasien yang telah mengalami sakit parah atau serius, namun mereka yang baru menderita gejala-gejala ringan yang tidak berbahaya sekalipun memerlukan manfaat diagnosa sehingga kesehatannya dapat terus terjaga. Sebuah naskah dari masa pemerintahan Kaisar Kuning (2696-2598 Masehi), Neijing Suwen menyatakan merawat penyakit setelah muncul layaknya menggali sumur setelah kehausan atau mengasah tombak setelah perang yang menandakan telah jauh terlambat. Alexano (2012:24-27) Dalam pengobatan cina diagnosa dilakukan dengan melihat kecenderungan $Q i$ (daya vital) pada pasien, apakah memadai dan sehat atau tidak. Selain itu perlu dipertimbangkan apakah terdapat beberapa substansi buruk dan jahat yang harus dihilangan dari tubuh pasien. Secara umum terdapat beberapa hal yang dapat dijadikan tolok ukur mendiagnosis penyakit yang menyerang seseorang seperti mengandalkan penglihatan, pendengaran, penciuman, perabaan, dan dialog. Permulaan diagnose dilakukan dengan pengamatan pasien yang matanya terlihat buram, berair, kurang kesadaran dan kewaspadaan sehingga kemungkinan menderita penyakit serius. Sementara orang yang sehat atau ringan maka matanya tampak bersinar serta jernih. Apabila kulit pasien tampak berwarna kemerahan berarti sedang mengalami panas yang tidak normal. Jika kulit pasien terlihat pucat menjadi pertanda tidak cukupnya $Q i$ di dalam darah akibat sebab-sebab tertentu. Sementara jika kulit pasien berwarna hijau kebiruan kemungkinan yang bersangkutan sedang didera kedinginan atau menahan rasa sakit yang tidak tertahankan. Urat nadi pasien pada pangkal hidung dan kedua matanya yang terlihat kebiruan menandakan terjadinya pelemahan limpa. Keadaan urat nadi pada sisi kiri jari telunjuk untuk pria dan sisi kanan untuk wanita juga perlu diperhatikan seperti 
panas, dingin, penonjolan, dan sebagainya yang menjadi pertanda tingkat keparahan suatu penyakit. Serupa dengan Alexano, pemeriksaan (infeksi) menurut Handoko (2008:88) dapat dilakukan untuk memeriksa daerah nyeri apakah ada luka, merah bengkak, berubah bentuk atau infeksi. Selain itu terdapat juga teknik pemeriksaan lidah untuk menentukan sifat atau jenis penyakit, apakah yin, yang, dalam, luar, dingin, panas, dan semacamnya. Aspek lidah yang diperiksa adalah warna, bentuk, gerakan otot, tebal-tipis, bersih-kotor, derajat basah-keringnya, serta yang lainnya.

Setelah pengamatan, diagnose dilanjutkan dengan mendengar dan mencium. Contoh ketika pasien mengeluhkan gejala pusing maka tabib akan mendengarkan hembusan nafasnya. Disamping itu dicermati juga cara bicara pasien yang disesuaikan dengan keluhannya serta dapat disertai penciuman aroma nafasnya. Misalnya ketika tercium bau busuk pada nafas pasien maka dimungkinkan yang bersangkutan mengalami keadaan penuh pada perutnya. Andaikata nafasnya sangat bau maka dapat mengindikasikan keberadaan makanan yang mengendap dan tidak tercerna dengan baik di perutnya. Sebaliknya bila nafasnya tidak berbau dapat menjadi pertanda kelemahan limpa. Perabaan dapat dilakukan dengan menepuk-nepuk kepala pasien, meraba wajah, memegang tangan, dan meraba perut. Melalui perabaan diketahui pula jumlah denyut nadi atau kondisi daerah sakit yang dikeluhkan pasien. Terkait denyut nadi, dalam pengobatan Cina terdapat 28 denyut nadi yang bisa menggambarkan keadaan pasien namun sangat sulit untuk dijelaskan. Ahli pengobatan Cina yang telah mumpuni mampu menafsirkan penyakit berdasarkan perbedaan denyut nadi.Menurut Handoko (2008:90) tujuan palpasi/ raba adalah untuk menentukan organ/ meridian yang terganggu, jenis kelainan yin/yang, serta menentukan sifat kelainan organ. Perabaan nadi dilakukan dengan memanfaatkan 3 jari dari jari telunjuk, jari tengah, hingga jari manis, tangan kiri digunakan apabila ingin memeriksa tangan kanan pasien begitu pula sebaliknya. Dialog dilakukan dengan mengungkapkan beberapa pertanyaan mendasar kepada pasien terutama berkaitan dengan lokasi rasa sakit yang dikeluhkan, lama keluhan yang diderita, nafsu makan, keadaan ekskresi, suasana hati, kenyenyakan tidur, dan sebagainya. Sesudah pertanyaan-pertanyaan yang bersifat mendasar, seterusnya dapat dilanjutkan dengan penggalian informasi yang lebih mengkhusus. Misalnya untuk kasus batuk, bisa diperinci lagi apakah batuk itu kambuh hanya pada malam hari atau setiap waktu demikian pula dengan warna dahak serta perawatan-perawatan yang pernah dicoba. Terkait penggalian informasi melalui dialog, Sun Si-miao (590-682 Masehi) seorang ahli pengobatan yang termashyur pada masa pemerintahan Dinasti Tang yang menyatakan lebih baik mengobati sepuluh orang laki-laki daripada seorang wanita. Lebih baik mengobati sepuluh orang wanita daripada seorang bayi. Bayi yang belum mampu diajak berkomunikasi tentu sangat sulit ditanya 
mengenai lokasi rasa sakit yang dideritanya.Sementara Handoko (2008:86) menyatakan jika anamnesis/bertanya (wen) berkaitan dengan riwayat/ kronologis penyakit yang diderita pasien seperti penentuan lamanya keluhan dirasakan, sifat nyeri, pemeriksaan darah, kebiasaan hidup, keadaan emosi, tanggal datang bulan terakhir (bagi wanita), pola hidup, sering tidaknya berolahraga, intensitas berhubungan seks, pola pekerjaan, serta pola makan dan minum. Sifat nyeri apakah berdenyut, tegang, atau kencang mesti ditelusuri serta diketahui penyebabnya yang berkaitan dengan diidapnya penyakit dalam, penyakit hati, limpa, ginjal, jantung, maupun kencing manis. Pemeriksaan darah memang dapat dilakukan dengan cara-cara tradisional namun seiring kemajuan teknologi pengobatan Cina juga mulai memanfaatkan alat-alat medis untuk mengukur kadar kolesterol, trigliserid, asam urat, dan semacamnya. Dari kebiasaan hidup pasien diketahui apakah sering terkena penyakit luar yang bersifat angin, panas, api, lembah, kering, atau dingin. Handoko (2008:79-82) menyatakan angin berjenis dua yakni angin yin dan yang, yang turut membawa faktor luar seperti lembap, dingin, kering atau panas yang masuk ke tubuh melalui meridian serta dikenal sebagai masuk angin. Sifat berpenyakit pada angin naik ke atas dan menyebar keluar artinya yang diserang adalah bagian atas badan serta kemudian menyebar ke seluruh pori-pori kulit. Penyakit yang berkaitan dengan serangan angin adalah vertigo, kejang klonus, balls palsy, hidung buntu, muka bengkak, takut dingin, tremor (gemetar), kejang tetanus, nyeri kepala, tenggorokan nyeri/ gatal, dan badan berkeringat. Sementara organ yang dapat diserang angin melalui meridian $Q i$ adalah hati dan kandung empedu, cara kerjanya hati yang bersifat mengekang limpa serta lambung akan menyebabkan gangguan pada kedua organ tersebut sehingga timbullah mual atau gangguan pencernaan. Api berupa suhu panas yang berasal dari terik matahari maupun suhu ruangan yang panas. Penyakit yang bersumber dari api ditandai oleh gejala badan lemas, pingsan, kepala terasa berat, dada sesak, mual, muntah, nafsu makan berkurang, feces lembek, dan sejenisnya. Penyakit lembap dipicu oleh musim kemarau berkepanjangan yang disusul oleh musim hujan. Gejala penyakit lembap sepert tubuh serasa membawa beban berat, sendi terasa nyeri dan linu, kepala terasa berat, pusing, kulit keluar gelembung air yang kadang bernanah, air kencing keruh, atau mencret berdarah/ nanah. Penyakit kering bersumber dari musim rontok berkepanjangan yang tidak segera disusul musim hujan. Gelaja penyakit kering seperti kulit kering, mulut-hidung-tenggorokan kering, urine sedikit, sembelit, rasa haus, bulu/rambut rusak, serta batuk kering berdahak kental/ berdarah. Penyakit dingin disebabkan musim dingin berkepanjangan, terang bulan, musim hujan, malam hari, ruangan dingin, daerah pegunungan, dan sebagainya. Gelaja penyakit dingin adalah timbul gejala dingin, tubuh/ perut terasa dingin/ nyeri, mencret, urin banyak, kontraksi otot, takut dingin, tidak berkeringat,dan sebagainya. Keterkaitan emosi merupakan unsur dalam yang 
memicu gejala-gejala penyakit tertentu. Handoko (2008:82-83) memaparkan orang yang sering marah rawan terkena penyakit hati, rasa gembira membahayakan jantung, kecemasan membahayakan fungsi limpa, sedih/ khawatir dapat merusak paru, dan kaget/ takut berpotensi menyebabkan penyakit ginjal. Tanggal datang bulan terakhir perlu diketahui tabib untuk menentukan pasien sedang hamil atau tidak. Sementara pola kerja juga menjadi pertimbangan yang serius sebagaimana diungkapkan Handoko (2008:83-84), seperti terlalu banyak jalan ternyata tidak bagus untuk tendon dan hati sebagai penguasa tendon, terlalu lelah mengganggu hati, terlalu banyak tidur mengganggu jantung, terlalu banyak menganggur mengganggu peredaran darah dan $Q i$, terlalu banyak duduk atau bekerja sehingga berakibat letih mengganggu otot dan limpa, terlalu banyak bicara mengganggu pita suara dan paru-paru, terlalu banyak berdiri atau mengangkat beban mengganggu tulang dan ginjal, terlalu banyak membaca mengganggu jantung, hati, dan ginjal, serta pola makan yang tidak alami serta tidak higienis jelas memicu berbagai gangguan organ. Pola hidup bersangkutan dengan kebiasaan tidur, sering olahraga atau tidak bahkan olahraga berlebihan, atau terlalu banyak melakukan hubungan seks yang mengakibatkan gangguan pinggang. Jenis pekerjaan biasanya bersangkutan dengan cara kerja yang bermuara kepada gangguan-gangguan tertentu. Orang dengan jenis pekerjaan sama umumnya memiliki gangguan organ yang sama, misalnya juru ketik, tukang kayu, atau juru masak yang bekerja terus menerus umumnya didera ketegangan otot atau keletihan. Contoh lainnya para tukang kebun, kuli panggul, atau karyawan industri berat lazimnya menderita cedera otot dan tendon tulang akibat kerja berat. Gangguan akibat pola makanan dan minum yang tidak seimbang dapat diketahui berdasarkan jenis makanan atau minuman yang dikonsumsi secara berlebih. Mengkonsumsi bumbu masak yang terlalu banya menyebabkan terganggunya otot, perut, serta syaraf. Kelebihan konsumsi daging berakibat asam urat, nyeri sendi, penyumbatan pembuluh darah, serta gangguan otot karena jaringan otot kekurangan oksigen. Terlalu banyak makan nanas, emping, kembang kol, atau kacang-kacangan juga memicu asam urat. Makan terlalu banyak lemak, kuning telur, santan, minyak goreng, dan kacang-kacangan mengakibatkan penyempitan pembuluh darah serta gangguan otot. Konsumsi teh, bayam, tomat, dan air yang mengandung kapur menyebabkan sakit pinggang karena mengendapnya batu kapur di ginjal.

\subsubsection{Mesir Kuno, Babilonia, Mesopotamia, Yunani, dan India}

Basya (2015:356) menaksir jika masa mesir kuno kemampuan mendiagnosa penyakit diduga telah dikenal, Papyrus Pepres yang berangka tahun 1550 sebelum masehi memuat beberapa jenis penyakit seperti trachoma, sakit persendian, penyakit cacing, dan Billharsia. 
Sementara Papyrus Edwin Smith yang diduga ditulis 1600 tahun sebelum masehi juga menguraikan sifat menyeluruh dari bermacam-macam penyakit, faktor penyebab, serta cara penanganannya. Sementara Bangsa Babilonia diduga telah melakukan pengkajian serius pada organ hati karena terdapat keyakinan jika hati merupakan organ yang sangat penting sebagai pusat kehidupan, perasaan emosional, maupun logika. York (2012:18-19) menduga berdasarkan bukti literatur-literatur kuno yang dapat ditemui, bangsa Mesopotamia telah mengenal tandatanda yang dapat dibaca pada tubuh pasien yang mengidap penyakit tertentu dari ujung kepala hingga ujung kaki dan para penyembuh dituntut memiliki kepekaan terhadapnya.

Delf dan Manning (1996:4-5) berpendapat pada mulanya orang Yunani yang mulai mencoba keluar dari wilayah mistis menduga jika penyakit bersifat alamiah sebagaimana halnya gerhana atau peristwa-peristiwa alam lainnya. Menidaklanjuti dugaannya tersebut orang Yunani mulai megadakan penyelidikan sebagaimana yang dilakukan oleh ahli perbintangan dalam meramalkan terjadinya gerhana. Orang Yunani menganut falsafahholistik dalam mengenali penyakit sehingga pada mulanya penyakit diasumsikan berasal dari sebab tunggal yakni ketidakseimbangan bagian-bagian cairan tubuh yang lebih dikenal sebagai empat humour yang terdiri dari empedu kuning, empedu hitam, darah, dan lendir. Basya (2015:358) menyatakan empat elemen yang merupakan temuan Hipocrates tersebut bersifat dingin, panas, kering, dan basah. Manusia dinyatakan sehat jika keberadaan keempatnya seimbang sebaliknya jika ada salah satu elemen mendominasi yang lainnya atau bercampur dengan elemen lain maka berakibat sakit. Gallienus (130-201 sebelum masehi) melakukan penyembuhan setelah sebelumnya dilakukan pemeriksaan atas fases dan urin pasien. Doktrin empat humour tubuh dihimpun dengan lebih meyakinkan oleh Gallienus serta berhasil menguasai alam kedokteran sekitar 1500 tahun.Basya (2015:359-361) menegaskan para dokter di Arab Pra Islam telah mampu mengidentifikasi gejala-gejala penyakit sepert demam, malaria, sakit kuning, sakit hati, sakit kandung kemih, kencing batu, sakit mata, sakit gigi, penyakit gusi, kudis, lepra, dan sebagainya. Setelah datangnya risalah Islam, kedoteran Arab diramaikan oleh penyembuhpenyembuh kesohor seperti Al-Harist bin Kidlah Ats-Tsaqapi, Zuhair bin Jannab Zaenab, Ibnu Judzaim, Ibnu Abi Ratsmah At-Tamimi, dan An-Nadhr bin Al-Harist. Sedangkan pada masa setelah Islam (Dinasti Umayah) menurut Basya (2015:373) kedokteran Arab mulai terkena pengaruh aliran Yunani, diagnose dilakukan oleh para tabib dengan mengamati wajah, mata, lidah, kuku, denyut jantung, dan urine pasien.

Sementara dalam Agama Hindu berdasarkan pendapat York (2012:26) pengetahuan Ayurveda sesungguhnya telah dijadian pedoman oleh para penyembuh dan ditransformasi secara lisan semenjak zaman Veda (1500-500 tahun sebelum Masehi). Menurut Nala (2001:1-49) 
terdapat berbagai istilah berkaitan dengan deteksi penyakit sepertirupa nidana menurut metode Charaka, Panca Nidana, Pariksha, Astasthana Pariksha, dan Dhatu Waisamya.Charaka dalam Charaka Samhita menyebutkan tiga metode untuk memeriksa penyakit yakni aptopadesa (berdasarkan pendapat orang suci/ ahli pengobatan yang memiliki pengetahuan matang), anumana (penarikan kesimpulan berdasarkan pengalaman atau pertimbangan logika), dan pratyaksa (pengamatan dengan mengandalkan panca indera). Panca Nidana terdiri atas Nidana (pengetahuan tentang etiologi/ sebab penyakit), purva rupa (pengetahuan mengenai gejala awal penyakit), rupa (pengetahuan tentang gelaja lanjutan dari penyakit), upasaya (pengobatan eskploratif/ penyelidikan), dan samprapti (pengetahuan tentang proses terjadinya penyakit). Pariksha meliputi darsana (mengamati tubuh pasien secara menyeluruh), prasna (wawancara dengan pasien), sparsana (pemeriksaan dengan memanfaatkan panca indera). Astasthana Pariksa dilakukan melalui nadi pariksa (pemeriksaan denyut nadi), mukha pariksha (pemeriksaan wajah), netra pariksha (pemeriksaan mata), ostha pariksha (pemeriksaan mulut), jihva pariksha (pemeriksaan lidah), danta pariksha (pemeriksaan gigi), nakha pariksha (pemeriksaan kuku), mutra pariksha (pemeriksaan air kencing), dan sakrt pariksha (pemeriksaan kotoran). Dhatu Vaisamya terdiri dari purva rupa (gejala awal), chaya (citra/ kesan), prakapa(metabolisme), prasara(perkembangan/ penyebaran), dan rupa (gejala nyata).

\subsection{Aspek-Aspek Tatěngĕr}

Terdapat beberapa aspek dalam tatěngěr usadha Bali yang dikenal sebagai sapta tayakni :

\section{a. Tanya (Komunikasi)}

Seorang balian umumnya akan mengambil waktu sejenak sebelum menangani pasien. Kesempatan inilah yang digunakan untuk melakukan komunikasi baik dalam arti bercakapcakap dengan pasien beserta keluarganya maupun dengan sesuhunan yang diiringnya. Komunikasi gaib lazimnya dilakukan oleh BalianKatakson atau Balian Kapican yang tidak mendasarkan dirinya pada proses belajar. Meskipun demikian ada pula beberapa balian yang mempelajari ilmu kawisesan dari seorang guru pendengaran bathinnya menjadi peka sehingga mampu mendengar suara-suara halus yang berasal dari alam gaib. Proses ketika sang balian melakukan komunikasi gaib dikenal dengan nguntab sesuhunan, ngeregepang, maupun sebutansebutan lainnya. Balian yang murni mengandalkan komunikasi gaib dalam menentukan penyakit pasien umumnya tidak terlalu membutuhkan keterangan yang detail dari si sakit maupun keluarganya, bahkan penjelasan atau keluhan yang terlalu bertele-tele bagi sebagian balian 
semacam ini dianggap mengganggu keheningan pikirannya ketika berhubungan dengan alam gaib.

Pasien semestinya hanya menjadi penonton laku gaib sang balian dan baru menjawab ketika ditanya. Penjelasan yang diberikan balian semacam ini tidak terbantahkan sebab bukanlah bersumber dari alam manusia. Penulis pernah mendatangi tempat praktek Balian A yang mengandalkan bisikan gaib dalam menentukan penyakit pasiennya. Ketika ada pasien yang nangkil memohon kesembuhan Balian A mengangkat tangannya dengan telapak tangan mengadap ke depan, kemudian segala pertanyaan yang diajukan pasien dijawab satu per satu. Balian A mengaku hanya menjadi perantara Ida Bhatara A, sesunggunya segala yang ia sampaikan kepada pasien merupakan sabda Ida Bhatara A. Sebagaimana Balian Katakson atau Balian Kapican secara umum, Balian A selalu merendah menyebut diri bodoh. Tentu jika analisa penyakitnya dibantah oleh Pasien, Balian-Balian Katakson/ Kapican akan menyerakan kembali segala bantahan tersebut kepada hakikat Sesuhunannya yang diyakini serba tahu. Sebagian besar pasien awam bahkan takut untuk membantah hasil identifikasi para Balian Katakson/ Kapican meski dirasa kurang tepat karena dikhawatirkan membuat murka sosoksosok gaib yang diiring sang balian. Cara ini sedikit berbeda dengan balian usadha yang karena kematangan ilmunya kemudian dianugerahi kemampuan untuk mendengarkan bisikan-bisikan gaib, sebagaimana BalianByang cukup tenar pada suatu wilayah. Si balian menuturkan kepada penulis jika kemampuan yang dimilikinya bermula dari aktivitas nyastra (mengolah silabelsilabel suci dalam tubuh) yang dipelajarinya dari seorang guru. Jika balian katakson biasanya mengadap ke pengarumannya untuk memohon petunjuk, balian usada terksan lebih santai.

Proses mengheningkan cipta cukup dilakukan di teras rumah dalam posisi berhadaphadapan dengan pasien.Sedangkan untuk balian usadha, balian uwut, balian tulang, dan sebagainya yang mengandalkan komunikasi non gaib mencari tempat sakit dengan mengandalkan komunikasi non gaib mencari tempat sakit maupun menyimpulkan penyakit berdasarkan keterangan-keterangan yang diberikan pasien maupun keluarganya. Menurut Pieter (2017:2) dalam komunikasi yang murni manusia tersebut terdapat dua orang individu atau lebih yang sedang melakukan hubungan tertentu yang masing-masing dari keduanya berupaya untuk saling mempengaruhi seperti membentuk opini, pemikiran, penilaian, keyakinan, kepercayaan, sikap, atau perilaku tertentu. Antara balian dan pasien membentuk hubungan yang saling mempengaruhi. Secara umum memang balianlah yang tampak dominan memberikan pengaruh karena otoritas yang dimilikinya. Pasien cenderung tampak sebagai pihak yang berkepentingan mencari pertolongan pada balian meskipun dalam perkembangannya kini semakin banyak penyembuh yang mempromosikan dirinya lewat berbagai media. Padahal bukanlah mustahil bila 
balian dipengaruhi oleh pasien dalam proses komunikasi. Contohnya balian yang sebelumnya memperkirakan penyakit tertentu yang diderita pasien, namun setelah mendengar keterangan pasien ia meragukan perkiraan awalnya beralih kepada perkiraan baru yang dirasa lebih tepat. Balian pemula hingga yang telah berpengalaman sekalipun seringkali menganggap keteranganketerangan pasien sebagai sesuatu yang berarguna untuk menangani kasus-kasus serupa yang terjadi selanjutnya. Jelaslah dalam upaya mengenali penyakit pasien tidak bisa dilepaskan dari pembentukan opini, pemikiran, penilaian, keyakinan, kepercayaan, sikap, maupun perilaku tertentu yang dapat bersifat positif maupun negatif. Jika kesemuanya bersifat positif maka kemungkinan kesembuhan maupun kepuasan dalam diri pasien menjadi lebih besar. Aktivitas komunikasi melibatkan berbagai aspek fisik, psikis, dan sosial, seorang balian harus berupaya mencari komposisi yang harmonis bagi ketiganya.

Pada hakikatnya penyakit menampakkan gejala-gejala secara fisik kendatipun sebabnya bersifat psikis, demikian pula sebaliknya penyakit-penyakit fisik patut diduga implikasi psikisnya pada pasien. Contohnya penyakit bebahi yang sebabnya adalah nonfisik menampakkan tanda-tanda yang aneh pada kelakuan pasien yang dapat diamati secara visual oleh balian. Beberapa balian juga mencari tanda-tanda jerawat yang berlebihan atau bercakbercak merah yang khas pada kulit wajah serta ada tidaknya kelainan syaraf pada wajah pasien yang diduga terkena guna-guna. Sebaliknya penyakit lepra (sakit gede) yang tergolong penyakit fisik pastilah memberi dampak psikis berupa rasa tidak percaya diri. Lingkungan sosial sendiri patut dilihat dalam konteks pasien sebagai makhluk bermasyarakat yang tidak dapat hidup sendiri. Individu yang sehat sekalipun tidak mampu hidup dalam kesendirian apalagi yang tela terjangkit penyakit sehingga produktivitas fisik ataupun psikisnya teregresi. Aspek sosial berkaitan dengan penerimaan, kepedulian, dan beban individu-individu di sekitar si sakit. Dalam identifikasi penyakit aspek sosial dapat menjadi informan bagi balian terutama pada pasien yang tidak mampu atau tidak lengkap dalam menerangkan gejala-gejala penyakitnya. Lebih lanjut Pieter menjelaskan bahwa proses komunikasi dipengaruhi oleh perbedaan karakteristik individual, sifat, watak, kepribadian, pengalaman, usia, pekerjaan, pendidikan, latar belakang budaya, sosial, ekonomi, agama, ras, suku bangsa, dan sebagainya. Tentu yang paling menarik dari semua aspek itu ketika mengkaji sistem pengobatan yang berbasis agama dan budaya adalah latar belakang budaya, agama, ras, maupun suku bangsa. Sebab belakangan para balian tidak hanya didatangi oleh pasien orang Bali yang beragama Hindu. Disinilah dituntun kemampuan seorang Balian dalam melakukan identifikasi penyakit dengan tanpa melanggar nilai dan norma yang dianut pasien. Dalam praktik medis modern seorang perawat selain wajib memiliki kemampuan akademis ilmu keperawatan, mereka juga wajib mempunyai keterampilan 
berkomunikasi dengan baik, efektif, dan tepat sasaran. Pada Usadha Bali sesunggunya serupa terlebih sistem pengobatan tradisional Bali bersangkutan dengan pola manyama-braya yang kental. Hubungan antara balian dan pasien tidak mesti diterjemahkan secara transaksional belaka.

\section{b. Tĕlěng/Tĕlĕb}

Sebagai tokoh agama,balian diyakini memiliki kekuatan penglihatan yang menyembuhkan (dharsan). Seorang penyembuh di Bali dipahami sebagai sang wikan yang tidak mendapatkan kemampuannya secara instan namun melalui proses belajar yang panjang. Balian bukan cuma digjaya menaklukkan kekuatan-kekuatan negatif yang mengganggu pasien tetapi yang terpenting adalah sanggup menaklukkan segala nafsu pada dirinya. Pemusatan pikiran dan pengekangan indera-indera diyakini membangkitkan kepekaan khas yang tidak dimiliki manusia pada umumnya. Di Bali beredar berbagai variasi cerita tentang seorang anak manusia yang berniat menjadi balian, menjalani proses penggemblengan, serta melewati proses pengujian yang menentukan layak tidaknya orang yang bersangkutan menyandang gelar balian. Sebagian versi cerita melukiskan jika sang calon balian diuji oleh gurunya di kuburan yang angker. Kebanyakan yang mau buka mulut menuturkan proses serta sensasi-sensasi yang dirasakan adalah mereka yang gagal, ketika digembleng dalam keheningan kuburan yang menyeramkan tetiba muncul perasaan takut tidak terperi sehingga memutuskan untuk melarikan diri dan melupakan cita-cita menjadi balian. Versi kisah gagal lainnya menggambarkan si calon balian hendak dianugerahi kekuatan supranatural oleh sang guru pada suatu tempat (bukan di kuburan yang seram) tetapi ketika diperintahkan untuk mengheningkan pikiran gagal terfokus oleh suarasuara dalam kepalanya sendiri maupun suara binatang-binatang di luar dirinya. Sementara mereka yang sukses menaklukkan dirinya sendiri dalam menerima anugerah sang guru hampir seluruhnya bungkam tidak mau menuturkan apa yang terjadi dalam proses tersebut. Seorang penyembuh di Bali setara dengan yogin yang terbiasa berkonsentrasi total pada suatu objek, dalam hal ini si sakit secara utuh. Jadi tidak ada yang dilewatkan oleh balian yang telah mumpuni nĕngĕrin lara, keterpusatan pandangan pada suatu objek dengan bersungguh-sungguh inilah yang dinamakan dengan tĕlĕng. Tentu saja tĕlĕng didasari oleh tĕlĕb (pengetahuan yang matang), jika tidak didasari oleh tělěb tentu tělĕng tidak aka nada gunanya. Kalaupun mampu melakukan tělĕng dengan sempurna jika tidak tahu apa tujuan dan hal yang dicari dalam proses tersebut tentu tidaklah berguna. Orang yang gagal dalam proses penggemblengan menjadi balian kebanyakan menerima nasibnya dengan lapang dada sebab menyadari jika dirinya yang tidak 
punya kualitas menjadi panĕngĕr gering yang baik tetap memaksakan kehendak maka risikonya sangatlah tinggi.

\section{c. Tahen/ Tureksa}

Tahĕn berarti menyentuh bagian tubuh pasien yang sakit maupun bagian-bagian lain yang berkaitan dengan suatu penyakit. Melalui penyentuhan yang hati-hati dengan pemberian penekanan tertentu balian sekaligus melakukan pemeriksaan (tureksa). Dalam proses Tahĕn dengan maksud tureksa balian mengandalkan kepekaan indera peraba yang terletak pada ujung jari-jarinya, dari sana akan diketahui suhu, terjadinya pembengkakan, denyutan, dan sebagainya. Misalnya dengan menekan bagian pusar pengidap penyakit perut yang diduga terkena sula seorang balian yang terlatih akan mengetahui apakah sula yang diderita pasien sula nadi atau sulabiasa dari denyutan yang dirasakan. Demikian pula untuk mendeteksi bĕtĕg balian umumnya akan menekan bagian yang bengkak kemudian diamati apakah bekas tekanan itu kembalinya cepat atau tidak. Bila bekas tekanan lama membekas maka disimpulkan pembengkakan yang diderita tergolong parah. Tekanan yang terukur dapat juga digunakan untuk mendeteksi organ dalam yang bermasalah. Apabila pada bagian yang ditekan pasien merasakan sakit maka dapat disimpulkan organ dalam yang bermasalah. Kendatipun pengetahuan tentang pembedahan dalam Ayurveda tidak diadopsi oleh ilmu usadha Bali namun pengetahuan tentang organ dalam yang tertulis dalam manuskrip-manuskrip usadha dapat dikatakan mencapa level yang mengagumkan. Ada yang memelesetkan ngusadain dengan ngusudin(menyentuh), disini para pasien mengharapkan sparsam (sentuhan) dari sang balian. Bagi beberapa pasien yang fanatik sentuhan balian dianggap sangat bertuah. Penulis pernah menjumpai seorang penyembuh ketika anaknya sakit panas dan telah dibuatkan ramuan penurun panas. Ketika seorang balian senior berkunjung ke rumahnya si penyembuh berkata, "Kemu usudin malu cucune" (sana sentuh dulu cucumu). Berarti sentuhan si balian senior yang tanpa sarana dianggap lebih ampuh dari campuran tetumbuhan khusus yang digodok dengan hati-hati. Bagi pasien boleh saja sentuhan si balian diyakni sebagai mukjizat namun bagi si penyembuh sendiri penyentuhan tetaplah proses penggalian informasi untuk menentukan obat, perlakuan, maupun prediksi atas perkembangan suatu penyakit di kemudian hari.

\section{d. Tanda}

Tanda menentukan hidup mati pasien, umur penyakit, dan sebagainya. Melalui kemampuan membaca tanda yang baik seorang penyembuh tidak kelabakan dalam menentukan keputusan sehingga terhindar dari malu atau citra kurang professional. Penyembuh-penyembuh 
yang tidak pandai membaca tanda dengan optimismenya yang meledak-ledak tiba-tiba patah hati karena pasiennya meninggal dunia. Melalui pembacaan patěngěraning pati urip dengan tepat si penyembuh sedini mungkin dapat memberi penguatan secara psikologis bagi keluarga pasien yang besar kemungkinannya akan menemui ajal, meskipun tidak secara terang-terangan menyatakan jika si pasien sudah tidak tertolong lagi. Demikian pula kepada si sakit yang akan menuju alam kematian disentuh dengan ajaran-ajaran ketuhanan yang bersifat membebaskan. Banyak balian yang demikian dihormati oleh orang-orang sekitarnya bukan karena luput dari kegagalan dalam menyembuhkan pasien-pasiennya. Manfaat yang paling penting tanda bagi balian dalam menjaga citra keprofesionalannya adalah sebisa mungkin agar jangan sampai ada pasien yang menemui ajal di tempat prakteknya. Di Bali apabila ada pasien yang menemui ajal di rumah balian maka akan menyebabkan susud taksu (hilangnya wibawa) yang dimiliki oleh balian yang bersangkutan. Pada saat yang sama diyakini taksu telah maleceat (sirna) sehingga balian yang bersangkutan kembali menjadi manusia biasa yang tidak memiliki keistimewaan. Selain karena dinilai belum matang dalam membaca tanda, balian yang kecolongan oleh kematian pasien di tempat prakteknya menyebabkan tempat tersebut mendapat labeling sebel (kotor). Orang Bali meyakini jika tempat praktek balian adalah tempat suci yang menjadi prsinggahan kekuatan suci para dewa dalam menganugerahkan kesembuhan. Dengan demikian setelah seorang pasien menemui ajal pada suatu tempat praktek seorang balian maka tidak akna ada lagi orang yang datang (nangkil) guna memohon kesembuhan. Dalam perkembangannya ada balian yang mensiasati kemungkinan-kemungkinan terburuk yang akan terjadi pada pasien dengan merumahkan pasien-pasiennya pada lokasi yang berjauhan dengan pangarumannya. Pada suatu daerah pernah pula penulis dengar pasien yang meninggal ketika berusaha diobati oleh seorang balian tetapi untuk menghindari susudnya taksu balian yang bersangkutan si pasien dinyatakan baru meninggal setelah tiba di rumah sakit. Meskipun demikian cara-cara antisipasi semacam itu tentu tidak dapat menyembunyikan secara sempurna ketidakprofesionalan yang masih menganga lebar dalam diri balian.

\section{e. Tangar}

Tangar adalah merupakan manifestasi dari kehati-hatian dan ketelitian yang harus dimiliki oleh seorang balian. Sekali lagi tangar tidak mungkin bisa diperoleh secara instan tanpa penggemblengan yang panjang. Balian yang tangar selalu merasa diri sebagai orang baru dalam dunia penyembuhan dan mengesampingkan sifat jumawa meskipun pada kenyataannya telah lama berpraktik sebagai balian. Sifat-sifat tinggi hati, emosi, nafsu, dan sebagainya tidak akan mampu menggoyahkan balian yang tangar. Secara metafsik diyakini bahwa penyakit-penyakit 
yang berhubungan dengan aspek magis dapat berubah menjadi gelaja lain sehingga membingungkan balian-balian yang belum berpengalaman. Sementara balian yang telah teguh dalam sasana (taat azas) memiliki daya panyĕnar (penghilang selubung tipuan) sehingga wujud asli dari suatu penyakit dapat diketahui. Bila terlena oleh tipuan-tipuan yang berasal dari kekuatan magis tentu berakibat salah penyimpulan, selanjutnya keliru memberikan penanganan atau malah memberikan obat-obatan yang berbalik membahayakan jiwa pasien. Dalam obrolanobrolan seputar dunia penyembuhan di Bali sudah menjadi hal lumrah jika suatu kekuatan gaib yang menjadi sumber sakit dapat meloncat ke bagian-bagian sensitif pasien. Penyembuh yang akan melakukan penyentuhan tentu serba tidak enak jika si pasien berbeda jenis kelamin atau balian yang tidak waspada dapat jatuh harga dirinya dengan labeling walian jaruh (dukun cabul). Peringatan yang lebih rasional sering dipesankan oleh balian-balian senior agar berhatihati terutama ketika menangani pasien yang merupakan lawan jenisnya, selain dapat berumber dari dorongan magis munculnya perilaku cabul memang berasal dari diri si penyembuh yang belum mampu menaati sasana kabalianandengan mapan. Melalui kewaspadaan, seorangbalian dapat menjauhan dirinya dari jebakan atau olok-olok. Di Bali bukan hanya orang yang benarbenar sakit yang mendatangi balian namun juga orang yang ingin menguji kemampuan seorang balian. Melalui pemahaman tanda yang baik seorang balian akan dengan cepat dapat menyimpulkan pasiennya benar-benar sakit atau pura-pura sakit. Pada suatu daerah di Bali pernah beredar kisah suatu remaja yang diantarkan oleh keluarganya ke tempat pratek suatu balian karena diduga menderita sakit buh (suatu penyakit dengan gejala perut membesar). Rupanya anak gadisnya dihamili oleh kekasihnya dan tidak berani berterus terang sementara orangtuanya pun tidak berpikir sejauh itu. Andaikata si balian tidak mampu membedakan tanda antara sakit buh dan hamil tentu sangat memalukan.

\section{f. Tĕnung}

Tenung berupa pembacaan aspek-aspek yang sekilas tidak ada hubungannya dengan penyakit namun dalam banyak kasus dapat membantu proses penyembuhan. Aspek-aspek yang dicermati oleh para balian ketika mendiagnosis suatu penyakit seperti hari kelahiran pasien, hari kambuhnya penyakit, keadaan pekarangan, gerak gerik, arah datangnya pasien, dan semacamnya. Ilmu kedokteran modern memang belum mampu menjangkau pengetahuan semacam itu bahkan dianggap tidak rasional. Meskipun demikian těnung menggambarkan betapa luasnya cakupan Usadha Bali yang melihat keterhubungan antara satu akibat dengan sebab-sebab yang sangat rumit. Terlihat sains kedokteran barat yang bercorak positivistik sangat terbatas dalam mendiagnosa penyakit, bahkan penyempitan analisis dianggap suatu keharusan 
untuk menghindari pembiasan yang malah membingungkan. Cara-cara semacam itu sah-sah saja namun perlu diingat upaya penyembuhan yang memajang label paling rasionalpun ternyata tidak selalu berhasil. Penerapan těnung tentu tidak boleh berada di awang-awang dengan tanpa melakukan pemeriksaan cermat atas penyakit yang diderita pasien.

\section{g. Tamba}

Tamba (obat) merupakan puncak dari pemeriksaan-pemeriksaan sebelumnya yang dilihat sebagai sesuatu yang holistik. Kesalahan satu tahap saja dalam proses nĕngĕrin lara makan akan berakibat pada kesalahan memberikan obat. Balian tidak akan mampu menolong pasien meskipun memliki něngěrin yang hebat jika tidak dilanjutkan dengan memberikan pengobatan. Kemampuan lain yang mesti dimiliki balian adalah keluasan wawasan sehingga mengetahui lokasi suatu bahan obat bisa diperoleh. Begitu juga dengan keasliannya, banyak balian amatir yang hanya berbekal membaca lontar atau mendengar menyarankan suatu bahan obat namun dirinya sendiri tidak mengetahui wujudnya, hal ini tentu sangat berbahaya. Dengan demikian balian selainharus cakap nĕngĕrin larasekaligus cakap nĕngĕrin tamba. Seorang balian dituntut mampu juga mencarikan pengganti suatu bahan obat apabila tidak dapat ditemukan.

\section{PENUTUP}

Pengobatan tradisional, khususnya usadha Bali memiliki masa depan yang sangat cerah. Kecerahan yang dimaksud karena ruang lingkupnya yang biner, meliputi aspek fisik maupun nonfisik. Keluasan kajian menyebabkan usadha Bali memiliki tantangan yang lebih besar pula tinimbang pengobatan medis. Dibutuhkan keseriusan, kesabaran, ketelitian, kehatihatian, dan sebagainya untuk menggambarkan pola pengobatan tradisional Bali terutama dalam hal diagnosa (tatěngěr) yang selama ini masih tampak layaknya kepingan-kepingan yang tidak beraturan. Bilamana penyusunan pola tidak segera dilakukan maka akan timbul kesan jika pengobatan tradisional Bali termasuk cara diagnosanya hanya bergantung pada kebetulan. Tentu semua orang yang menaruh cinta dan hormat pada usadha Bali tidak menginginkan system pengobatan ini hanya danggap sebagai dongeng yang tidak perlu dicermati dengan serius.

Perlu dipahami jika usadha Bali telah menyelamatkan banyak orang pada masa lampau, sebelum hadirnya pengobatan medis. Jelaslah bahwa usadha Bali berperan dalam menjaga kelestarian manusia etnis Bali sebagaimana yang dikenal kini. Anggapan bila usadha Bali merupakan cara pengobatan usang yang tidak mungkin dikembangkan di era postmodern karena mensyaratkan hal-hal tertentu yang berbau masa lampau mestinya disingkirkan. Orang Bali 
mesti optimis dengan system pengobatan tradisional yang dimilikinya. Buktinya cara-cara pengobatan tradisional lain yang berasal dari Cina, India, bahkan Jawa dapat bereksistensi dan bertahan di Bali. Sangat disayangkan jika system pengobatan tradisional lokal menemui kepunahan akibat ulah manusia Bali sendiri. Secara lebih luas lagi kepunahan aspek-aspek Usadha Bali menyebabkan putusnya rangkaian budaya pengobatan dunia yang terjalin dan saling mempengaruhi sejak lama. Tentu akan sangat sulit bahkan mustahil untuk menyusunan ulang jalinan serupa.

\section{DAFTAR PUSTAKA}

Alexano, Poppy.2012.Warisan Kuno Pengobatan Tiongkok.Jakarta:Dunia Sehat

Balint, Enid, Norell, J.S.1973.Six Minutes for the Patient.USA:Tavistock Publications Limited Basya, Ahmad Fuad.2015.Suumbangan Keilmuan Islam pada Dunia.Jakarta:Islam Utama

Delf, Mohlan H.,Manning Robert T.1996.Major Diagnosis Fisik.Jakarta:EGC

Hakim, Jusuf.2010.Mendiagnosa Penyakit Nonmedis. Jakarta:PT Elex Media Komputindo

Handoko, Pudjo.2008.Pengobatan Alternatif.Jakarta:PT Elex Media Komputindo

Hardjodisastro.2006.Menuju Seni Ilmu Kedokteran.Jakarta:PT Gramedia Pustaka Utama

Nala, Ngurah.2001.Ayurveda Ilmu Kedokteran Hindu.Denpasar:Upada Sastra

Permadi, Adi.2006.Tanaman Obat Pelancar Air Seni.Depok:Penebar Swadaya

Pieter, Herri Zan.2017.Dasar-Dasar Komunikasi Bagi Perawat.Jakarta:Kencana

Sugiharta, I Putu Suweka Oka.2018.Usada Bali dan Agama Hindu.Denpasar:Saka Foundation.

Suparti, Siti.2017.99++ Solusi Medis, Herbal \& Holistik Atasi Berbagai Penyakit.Jakarta:Penebar Plus.

York, William Henry.2012.Health and Wellness in Antiquity Through The Middle Ages.California:Greenwood 